JOURNAL OF SECURITY AND SUSTAINABILITY ISSUES

ISSN 2029-7017 print/ISSN 2029-7025 online

2021 Volume 11

https://doi.org/10.47459/jssi.2021.11.48

\title{
FORECASTING THE RESERVE MONEY OF THE CENTRAL BANK OF POLAND IN THE ASPECTS OF ECONOMY SECURITY ${ }^{1}$
}

\author{
Marcin Jurgilewicz ${ }^{1}$, Norbert Malec ${ }^{2}$, Juliusz Piwowarski ${ }^{3}$, Bartosz Kozicki ${ }^{4}$ \\ ${ }^{1}$ Rzeszów University of Technology, Poland \\ ${ }^{2}$ University of Natural Sciences and Humanities in Siedlce, Poland \\ ${ }^{3}$ University of Public Safety and Individual APEIRON in Krakow, Poland \\ ${ }^{4}$ Military University of Technology, Warsaw, Poland \\ E-mails: ${ }^{1}$ m.jurgilewicz@prz.edu.pl; ${ }^{2}$ norbek@poczta.fm; ${ }^{3}$ rektorat@apeiron.edu.pl; ${ }^{4}$ bartosz.kozicki@wat.edu.pl
}

Received 15 September 2021; accepted 11 November 2021; published 30 December 2021

\begin{abstract}
Forecasting of monetary policy tools, including reserve money of the Central Bank of Poland, in order to optimise economic decisions made by business entities operating on this market, becomes a basic canon of knowledge, in order to minimise a risk of undertaken economic operations - is currently the area of our investigation. The article raises a problem of forecasting the reserve money of the Central Bank of Poland on the basis of initial information received from the National Bank of Poland. The studies started with analysis and evaluation of time series of reserve money of the Central Bank in Poland. Then the analysed series were divided into two parts. Based on obtained results, the researchers performed forecasting of the first part of separated time series of reserve money of the Central Bank in Poland with the use of different methods. The above mentioned time series consists of 132 elements. Later on, the researches chose the best forecasting method and that was the basis for initial time series forecasting of reserve money of the Central Bank in Poland in mil PLN in retrospective terms during 2010-2021 for the next 2021-2022 years.
\end{abstract}

Keywords: value of reserve requirements; forecasting; COVID-19; Central Bank; economy security

Reference to this paper should be made as follows: Jurgilewicz, M. Malec, N., Piwowarski, J., Kozicki. B. 2021. Forecasting the reserve money of the central bank of Poland in the aspects of economy security, Journal of Security and Sustainability Issues, 11, 525-536. https://doi.org/10.47459/jssi.2021.11.48

JEL Classifications: G18

Additional disciplines: political sciences and administration, law

\section{Introduction}

Reserve requirements are considered as funds that constitute a certain part of deposits paid to commercial banks, which cannot be used to finance lending activities. These funds are transferred to a central bank account, which is run for each commercial bank. The analysis of source literature and authors' own experience show that institutions dealing with business forecasting use different methods of forecasting, including those inappropriate. In view of the foregoing, the authors became inspired to undertake studies in the field of forecasting. The research problem revolves around the choice of methods for forecasting the reserve money of the Central Bank in Poland, in order to optimise the obtained forecast results in the aspect of economic security of Poland. Dynamic in the research covers the years 2010-2021, and the executed forecast involves the year on a monthly basis. The aim of the study is to forecast the amount of monetary reserves held by the Central Bank in Poland

1 The article was financed from the funds received from the grant for support under the international grant project No. GA/23/2020 implemented by the Authors. 
for the years 2021-2022 in the aspect of the maintenance of economic security. The authors formulated the following research question: To what extent does the use of analysis and evaluation of time series of reserve money of the Central Bank in Poland in a retrospective perception allow for choosing an optimal forecasting method, in order to minimise the risk of financial undertakings and evaluate monetary policy of the state in the aspect of economic security? Literature related to forecasting issue is very extensive and dispersed. There are no accurate descriptions of methods for analysing and evaluating time series in a retrospective perception, building forecasting models and the ways of conducting in order to calculate the result of forecast. In terms of the following study, the most useful literature positions describing forecasts, but according to authors, they are not sufficient to conduct a detailed analysis and evaluation of considered in the study series of reserve money of the Central Bank in Poland. Analysis and evaluation carried out in a proper way and forecasting model built on their basis require also intuition and experience in this type of research. The article uses research methods in the form of literature analysis that relates to issues connected with the central bank reserves, forecasting, analysis of source documents, computer simulation method and comparisons. Forecasting of the considered retrospective data was performed with the application of three methods: Holt's, Klein and the ARIMA model. The best method turned out to be Holt's exponential smoothing which was used to forecast data on the amount of the required cash reserves of Central Bank for the years 2021-2022.

\section{Reserve requirement ratio and forecasting}

Reserve requirement rate, called also minimum reserve rate, is determined by the Central Bank for trade banks to stem excessive expansion in lending or stimulate credit activity of banks, depending on the needs of economy. Minimum reserves might refer to current, term and monetary contribution or without diversifying types of deposits (Owsiak, 2010, p. 79).

Maintaining the appropriate level of Central Bank reserves is extremely important from the point of view of economic security. Economic security is a state of reality that allows for the development of the economy and ensuring a proper standard of living for citizens through continuous access to raw materials, assets, technology or information (Szubrycht, 2006, pp. 87-98). The infectious disease COVID-19 undoubtedly had an impact on Polish economic security. The first case of the disease was reported in December 2019 in China (Tia, and others, 2020; Zhu, Zhang, Wang, Li X, Yang, Song, et al., 2020; Zimon, Jurgilewicz, Kmiotek, 2020). The infectious disease showed a rapid growing trend in various countries of the world and on March 11, 2020 WHO declared it a pandemic (E. Satomi, and others, 2020).

A large number of infected people and a high number of deaths have led to the introduction of many restrictions on the functioning of people in various countries of the world: the use of face masks, disinfectants, various types of travel restrictions and a ban on group gatherings (Yan et al., 2020; Pike, Saini, 2020). The COVID-19 pandemic led to a slowdown in the growth of world economies (Luisetto, Fiazza, Latishhev. 2020). It resulted in high levels of indebtedness in large economies, unfavorable demographic conditions in developed markets, a lack of political will to implement major structural reforms, and increased geopolitical and trade risks (https://global.beyondbullsandbears.com/pl/2020/07/27/kryzys-wywolany-przez-pandemie-covid-19przyspiesza-transformacje-cyfrowa/; as of 19.11.2020).

The COVID-19 pandemic has had and continues to have an impact on the level of the required monetary reserves of the Central Bank of Poland. Therefore, it is extremely important to constantly analyze and evaluate the level of required reserves from the past in terms of their forecasting for the future.

The methodology used in the study may involve the planning of other types of variables in any entity in which the same regularities will be detected from the analysis and evaluation of data from the past and on the basis of which it will be possible, through a critical analysis of the literature, to choose the correct methods for the forecasting for the future. Examples of data analysis in terms of the detection of regularities such as trend or seasonality on not only financial data but, above all, on quantitative variables can be found in many literature items (Luszniewicz, 2003, pp. 143-160; Kozicki, Waściński, Brzeziński, Lisowska, 2018, pp. 1235-1241; Ko- 
zicki, 2020; Rabej, 2018, pp. 43-278). However, the building of models itself for data forecasting is widely described in the literature by various researchers (Forlicz, 2012, pp. 333-349; Kuźniak, red. nauk. M. Podgrodzka, 2018, pp. 83-92; Skudlik, 2015, Puławska-Turyna, 2011; Chan Raymond H., Lee Spike Tsz Ho, 2014; Elliott, Timmermann, Economic forecasting; Franses, Dick van Dijk, Opschoor, 2014; Kot, Jakubowski, Sokołowski, 2011; Makridakis, Wheelwright, Hyndman, 1998).

The issue of forecasting the reserve money of the Central Bank in Poland that was taken up by the authors is important, because its growth or decrease effectively affects the size of money circulation in Poland and allows it to be limited. According to P. Dittmann, forecasting is a rational, scientific prediction of future events (Dittmann, 2016, p. 20), and its aim is to reduce the risk associated with making a mistake. This is very important while planning the reserve requirement ratio of the Central Bank. In market economies, the central bank plays an essential role. It performs three basic functions, such as: an issuing bank, a bank of the banks, a central bank of the state (Narodowy Bank Polski, 2021).

There are many different classifications of forecasting methods in the literature, but division of methods into quantitative and qualitative is one of the most commonly used. From the point of view of this study, the authors will use quantitative methods. The choice of appropriate methods will be preceded by an exact analysis and assessment of time series of ecology costs in the retrospective perception.

\section{The analysis and evaluation of time series of the Central Bank reserve money in millions of PLN during the years 2010-2021}

The research began with the outlining of the data obtained from the website of the National Bank of Poland concerning the amount of the required cash reserves held in Poland from January 2010 to August 2021. The data is outlined in Figure 1.

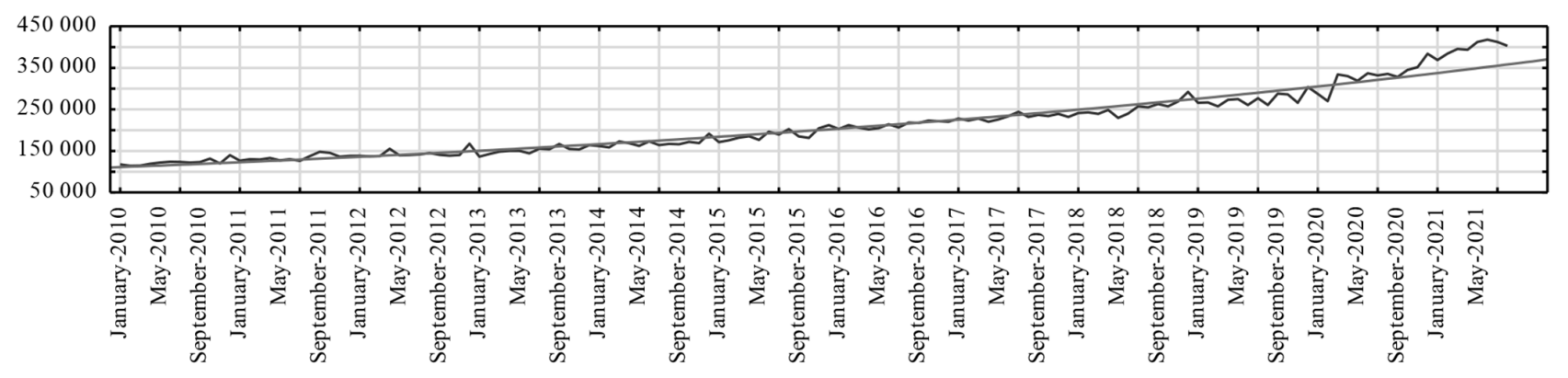

Figure 1. A linear graph of the number of required cash reserves of the Central Bank in Poland from January 2010 to August 2021 in million PLN

Source: https://www.nbp.pl/home.aspx?f=/statystyka/pieniezna_i_bankowa/rezerwowy.html (Date of access: September 29, $202 \overline{1}$.

The evaluation of the data presented in Figure 1 is the observation of regularities - an increasing trend. A function that takes an exponential shape was fitted to the outlined data. In total, 140 variables are presented in the chart. Their sum is PLN 29698992,59 million. The arithmetic mean of the analyzed data was PLN 212 135,66 and the median was PLN 202 373,79. Standard deviation was at the level of PLN 77 473,47 million. There was also a strong increase in the level of reserve requirements at the Central Bank in Poland caused by the COVID-19 infectious disease pandemic from March 2020.

The next stage of the research was the search for outliers and extreme values from the median of the analyzed data. To achieve this goal, a histogram was made (Fig. 2). 


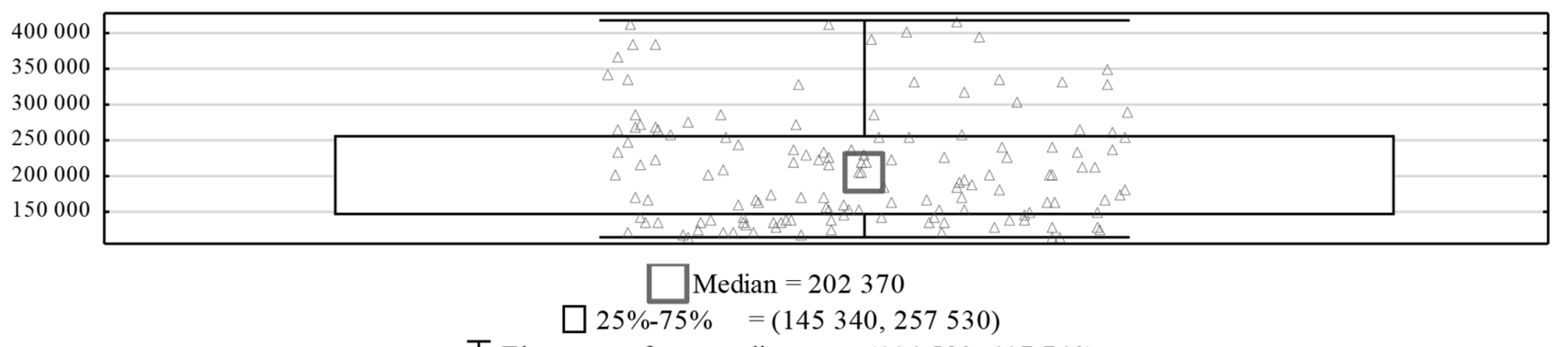

工 The range of non-outliers $=(114580,417740)$

$\triangle$ Raw data

Figure 2. Histogram of the amount of the required cash reserves of the Central Bank in Poland

Source: https://www.nbp.pl/home.aspx?f=/statystyka/pieniezna_i_bankowa/rezerwowy.html (Date of access: September 29, 2021.

The evaluation of the data presented in Figure 2 is that they lack outliers and extreme values. The lower limit of the outliers was PLN 114580 million and the upper one was PLN 417740 million. Then, the distribution of the data under consideration was investigated. For this purpose, a normality graph was made with the ShapiroWilk test. The results are outlined in Figure 3.

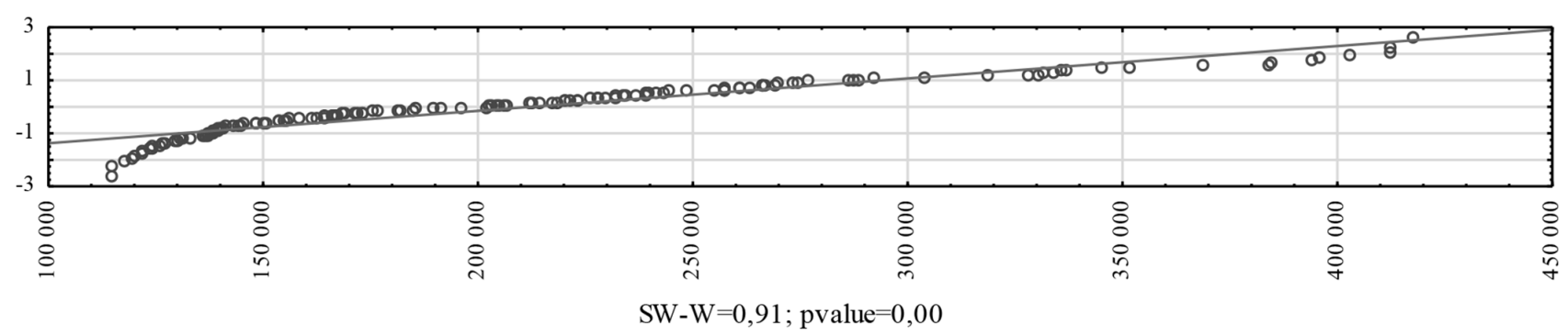

Figure 3. The normality graph with the Shapiro-Wilk test of the amount of the Central Bank's required cash reserves in Poland

Source: https://www.nbp.pl/home.aspx?f=/statystyka/pieniezna_i_bankowa/rezerwowy.html (Date of access: September 29, 2021.

The visual observation of Figure 3 shows that the distribution of the considered data is not normal. The lack of normality of the distribution is confirmed by the result of the obtained Shapiro-Wilk test where the $p$ value is lower than the significance level. Then, the relationship in the delays of the primary time series under consideration was investigated. To achieve this goal, the following were used: autocorrelation (Fig. 4) and partial autocorrelation (Fig. 5).

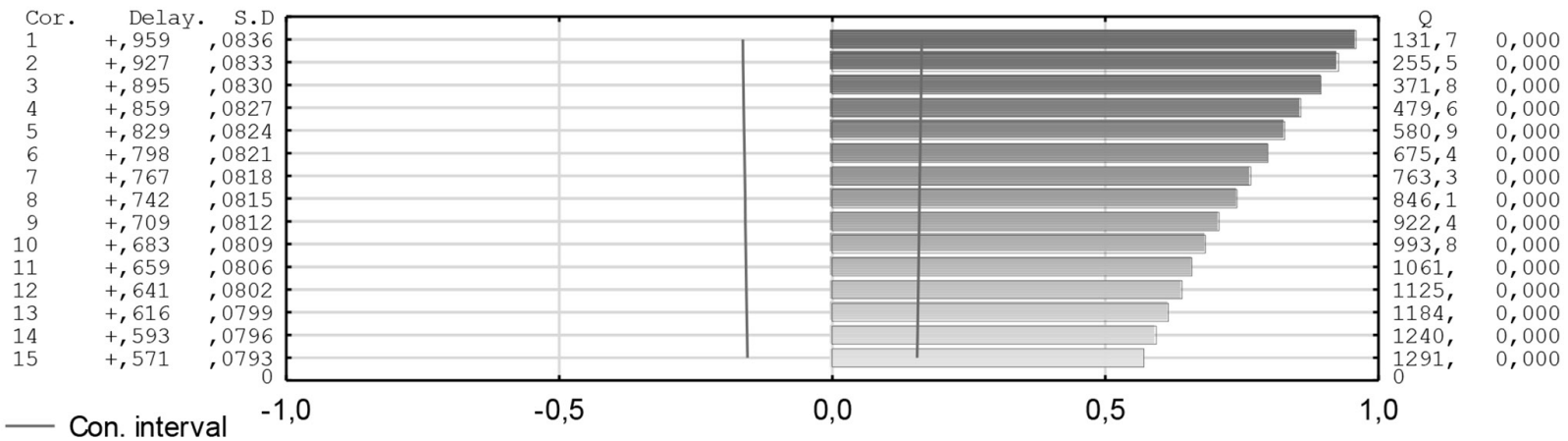

Figure 4. Autocorrelation of the amount of the required cash reserves of the Central Bank in Poland

Source: https://www.nbp.pl/home.aspx?f=/statystyka/pieniezna_i_bankowa/rezerwowy.html (Date of access: September 29, 2021. 
The autocorrelation (Fig. 4) indicates the existence of dependencies as an increasing trend. The respective autocorrelation coefficients are higher than two standard deviation and the Q statistic increases strongly. P value is below the significance level.

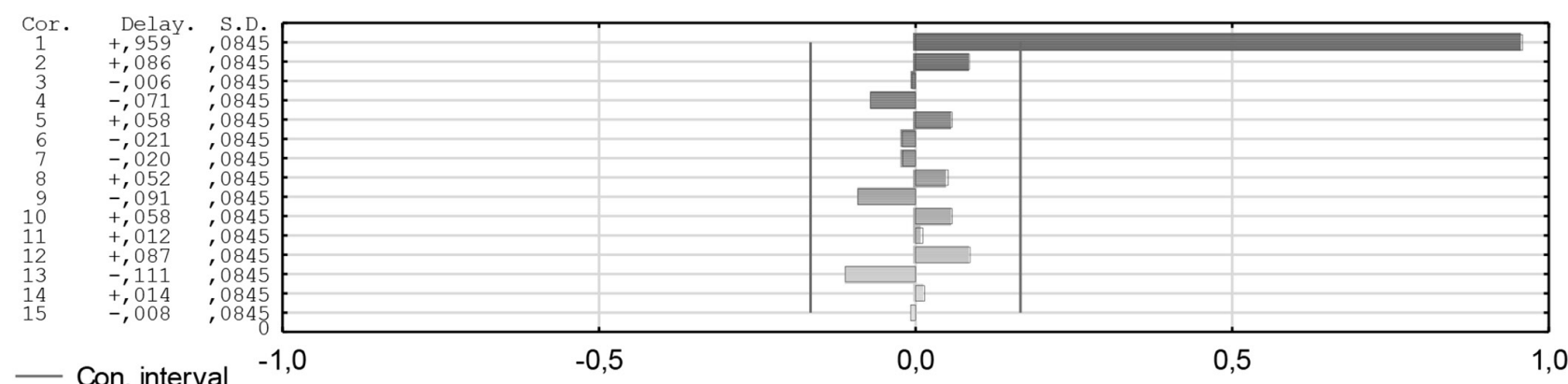

Figure 5. Partial autocorrelation of the amount of the required cash reserves of the Central Bank in Poland

Source: https://www.nbp.pl/home.aspx?f=/statystyka/pieniezna_i_bankowa/rezerwowy.html (Date of access: September 29, $202 \overline{1}$.

The partial autocorrelation (Fig. 5) confirms the strong upward trend of the considered primary time series.

The next stage of the research was to confirm the existence of the trend in the considered time series. To confirm the correctness, a model consisting of three predictors was built. Significant predictors are summarized in Table 1.

Table 1. Multiple regression model

\begin{tabular}{|c|c|c|c|c|c|c|}
\hline \multirow{2}{*}{$N=140$} & \multicolumn{6}{|c|}{$\begin{array}{c}R=, 98441518 R^{\wedge} 2=, 96907324 \text { Correctness } R 2=, 96839103 \\
\text { Standard error of estimation : } 13774\end{array}$} \\
\hline & $\mathbf{b}^{*}$ & $\begin{array}{c}\text { Standard } \\
\text { error }\end{array}$ & b & $\begin{array}{c}\text { Standard } \\
\text { error }\end{array}$ & $t(136)$ & $\mathbf{p}$ \\
\hline Absolute term & & & 100361,8 & 8634,398 & 11,62348 & 0,000000 \\
\hline t & $-0,551141$ & 0,141934 & $-1052,8$ & 271,118 & $-3,88307$ & 0,000160 \\
\hline $\mathbf{t}^{\wedge} 2$ & 1,353830 & 0,101562 & 17,8 & 1,333 & 13,33008 & 0,000000 \\
\hline Int & 0,210600 & 0,055492 & 17316,5 & 4562,833 & 3,79512 & 0,000221 \\
\hline
\end{tabular}

Source: https://www.nbp.pl/home.aspx?f=/statystyka/pieniezna_i_bankowa/rezerwowy.html

(Date of access: September 29, 2021.

The multiple regression model, which was constructed, fits very well. The adjusted R2 was 0,97 . The standard error of estimation was PLN 13774. Significant predictors confirm the existence of an exponential trend. The next stage of the research was the analysis and evaluation of the residuals of the constructed multiple regression model. Thus, a line graph of predicted and observed values was used (Fig. 6). 


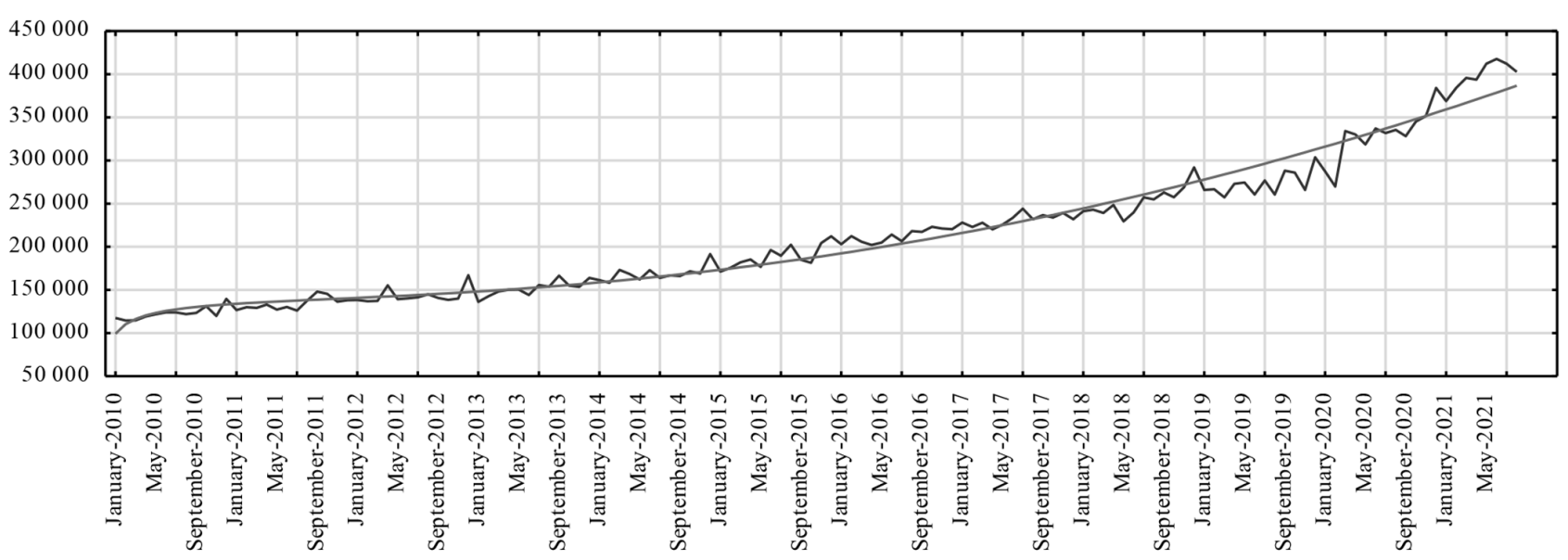

- Observed values

Predicted values

Figure 6. Line graph of predicted and observed values in million PLN

Source: https://www.nbp.pl/home.aspx?f=/statystyka/pieniezna_i_bankowa/rezerwowy.html (Date of access: September 29, 2021.

The evaluation of Figure 6 is a good match between predicted and observed values.

Then, in Figure 7, a line graph of the residuals of the constructed multiple regression model is outlined.

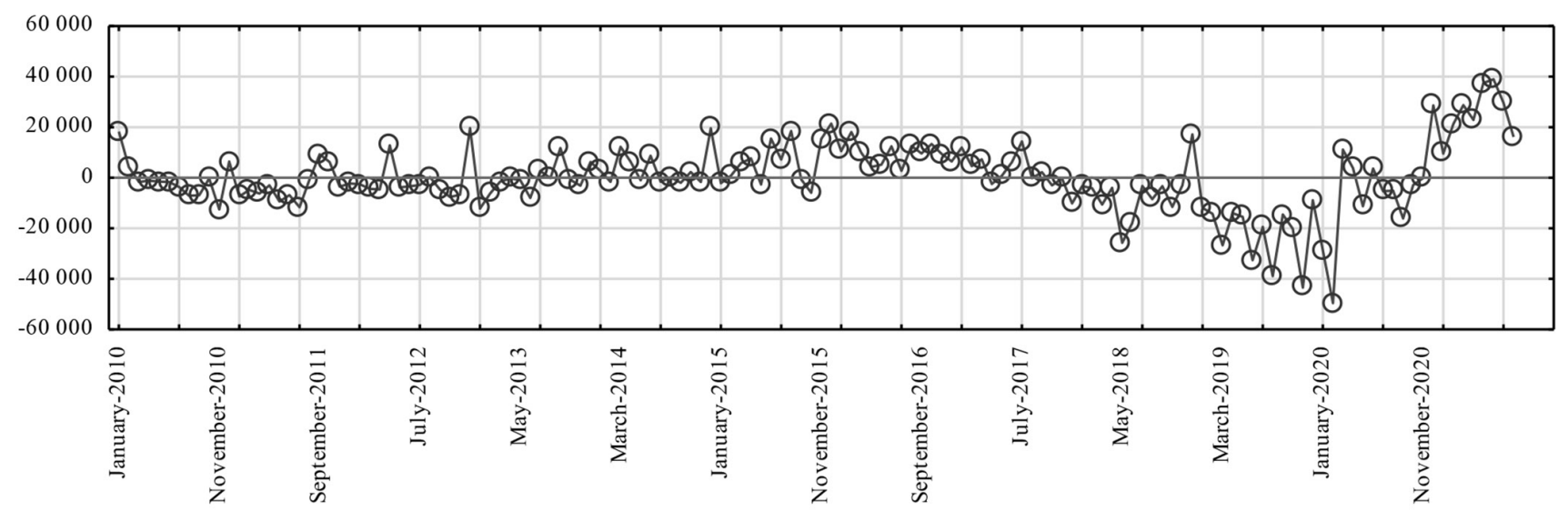

Figure 7. Line graph of the multiple regression model residuals in million PLN

Source: https://www.nbp.pl/home.aspx?f=/statystyka/pieniezna_i_bankowa/rezerwowy.html (Date of access: September 29, 2021.

The arrangement of the residuals of the constructed multiple regression model indicates the existence of a dependencies in their delays. This, in turn, is a premise for the use of autocorrelation (Fig. 8) and partial autocorrelation (Fig. 8). 


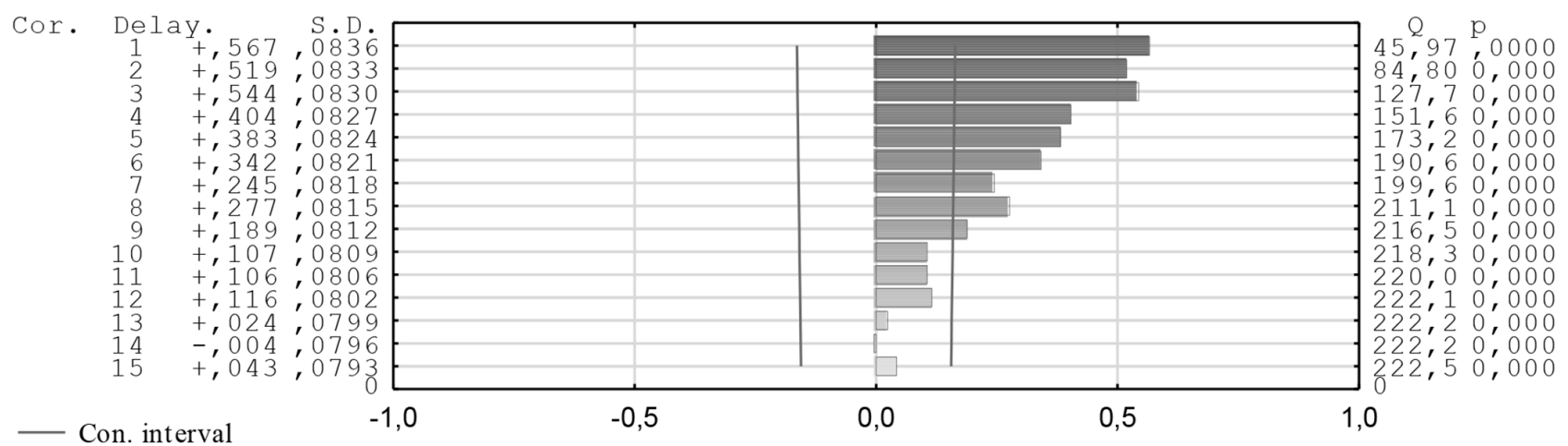

Figure 8. Autocorrelation of multiple regression model residuals

Source: https://www.nbp.pl/home.aspx?f=/statystyka/pieniezna_i_bankowa/rezerwowy.html (Date of access: September 29, 2021.

The autocorrelation (Fig. 8) indicates the existence of dependencies in the residuals of the constructed model and, thus, the absence of the white noise phenomenon.

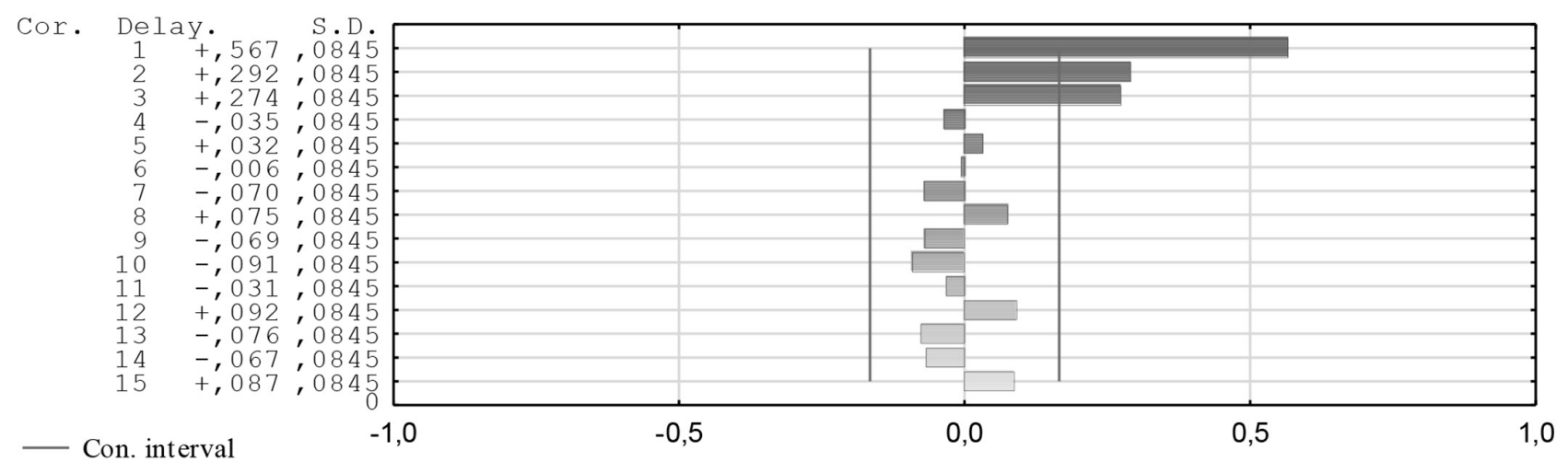

Figure 9. Partial autocorrelation of multiple regression model residuals

Source: https://www.nbp.pl/home.aspx?f=/statystyka/pieniezna_i_bankowa/rezerwowy.html (Date of access: September 29, 2021.

The partial autocorrelation (Fig. 9) confirms the existence of dependencies in the residuals of the constructed model. The evaluation of the conducted analyzes of the time series of the amount of cash reserves held at the Central Bank in Poland is the observation of a regularity as an upward trend. The analysis of the literature on the subject of the research shows that the best method for the forecasting of the considered data with such regularities is actually three methods: Holt's, Klein and the ARIMA model. To evaluate the forecasts obtained, the primary time series was divided into two parts: teaching and testing (Fig. 10). 


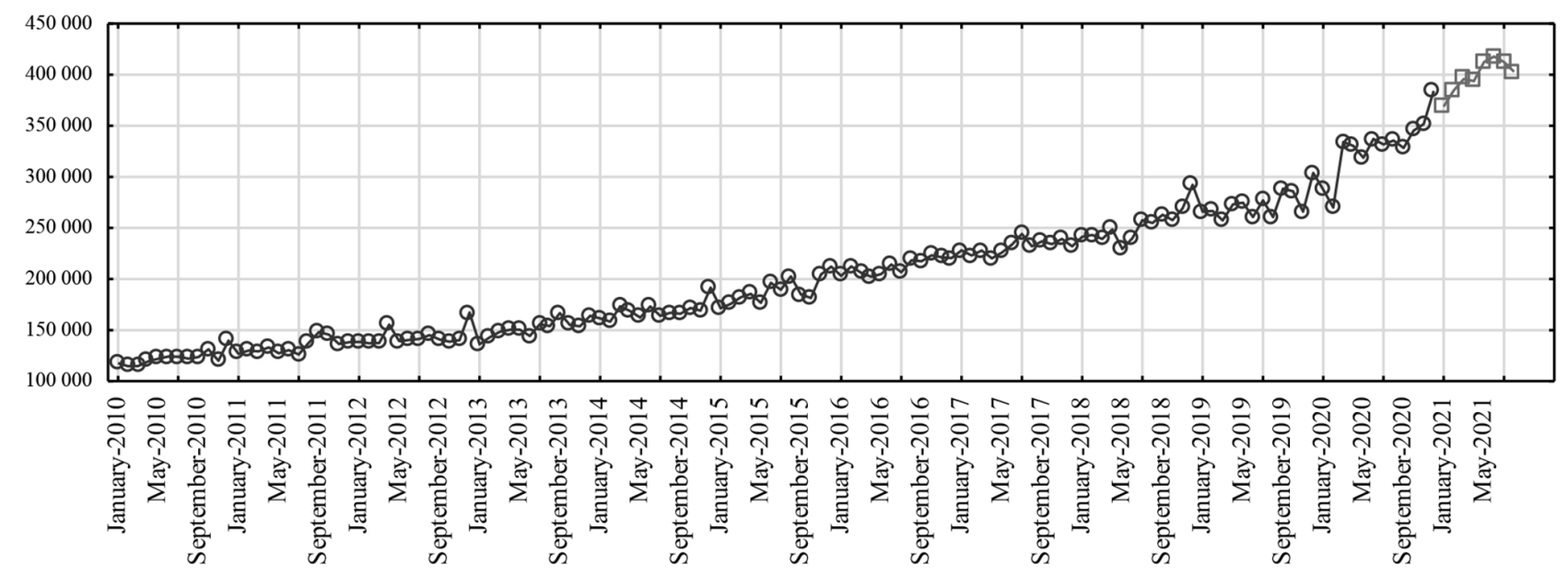

- A teaching series

$\square$ T est series

Figure 10. The division of the main time series into two parts: teaching and testing in million PLN

Source: https://www.nbp.pl/home.aspx?f=/statystyka/pieniezna_i_bankowa/rezerwowy.html (Date of access: September 29, 2021)

The teaching time series will be used to build forecasting models for the future and the testing one will be used to evaluate the obtained forecasts.

The forecasting results using three methods along with the testing time series are summarized in Figure 11.

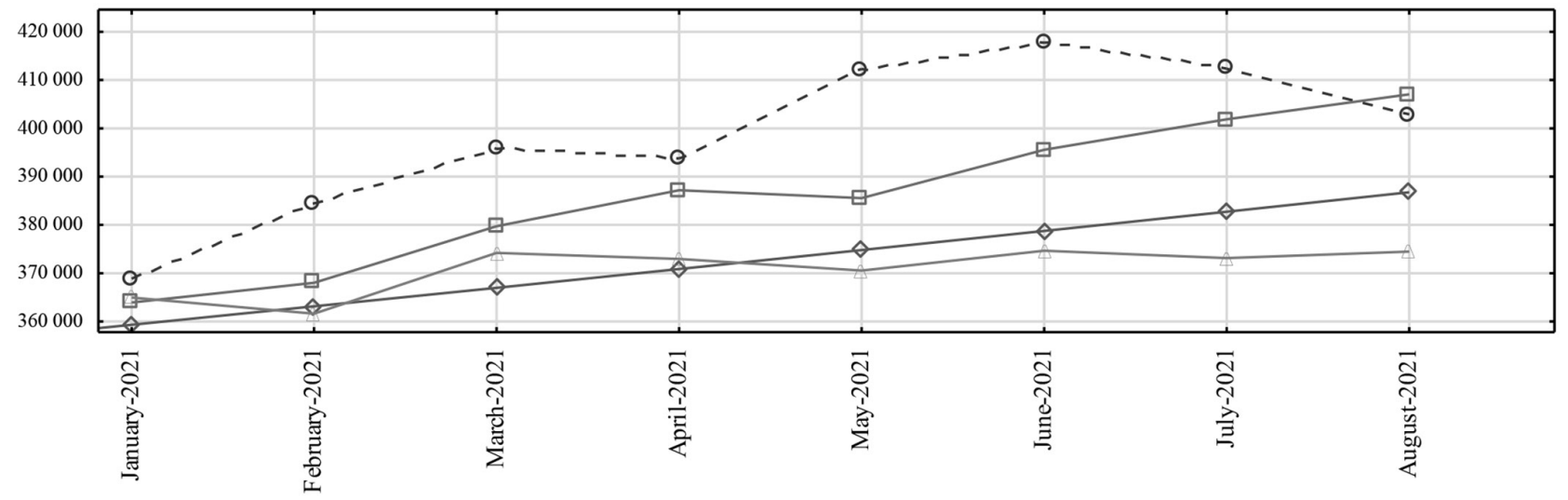

$-\Theta-$ Test series

$\square$ - Holt Model

$\diamond$ Klein Model

$\triangle \operatorname{ARIMA~Model~}(0,1,1)(0,0,1)$

Figure 11. Comparative analysis of forecasts made with the following methods: Holt's, Klein, ARIMA with a testing series in million PLN Source: https://www.nbp.pl/home.aspx?f=/statystyka/pieniezna_i_bankowa/rezerwowy.html (Date of access: September 29, 2021.

Visual observation of the information outlined in Figure 11 allows for the conclusion that the best method for the forecasting of the considered data for the future is the Holt's exponential smoothing method.

In order to confirm the observed regularity, the analysis of the error residuals of the obtained forecasts was performed in Table 2. 
Table 2. Forecasting errors analysis

\begin{tabular}{|c|c|c|c|}
\hline & Holt's & Klein & ARIMA \\
\hline MAPE & $3,33 \%$ & $6,36 \%$ & $6,84 \%$ \\
\hline
\end{tabular}

Source: https://www.nbp.pl/home.aspx?f=/statystyka/pieniezna_i_bankowa/rezerwowy.html (Date of access: September 29, $202 \overline{1}$.

The evaluation of the forecast error analysis conducted in Table 2 is that the best forecasting method is Holt's exponential smoothing. This became a premise for the forecasting of the considered time series of data on the amount of required cash reserves held by the Central Bank in Poland. The forecasting results for the years 2021-2020 are summarized in Figure 12.

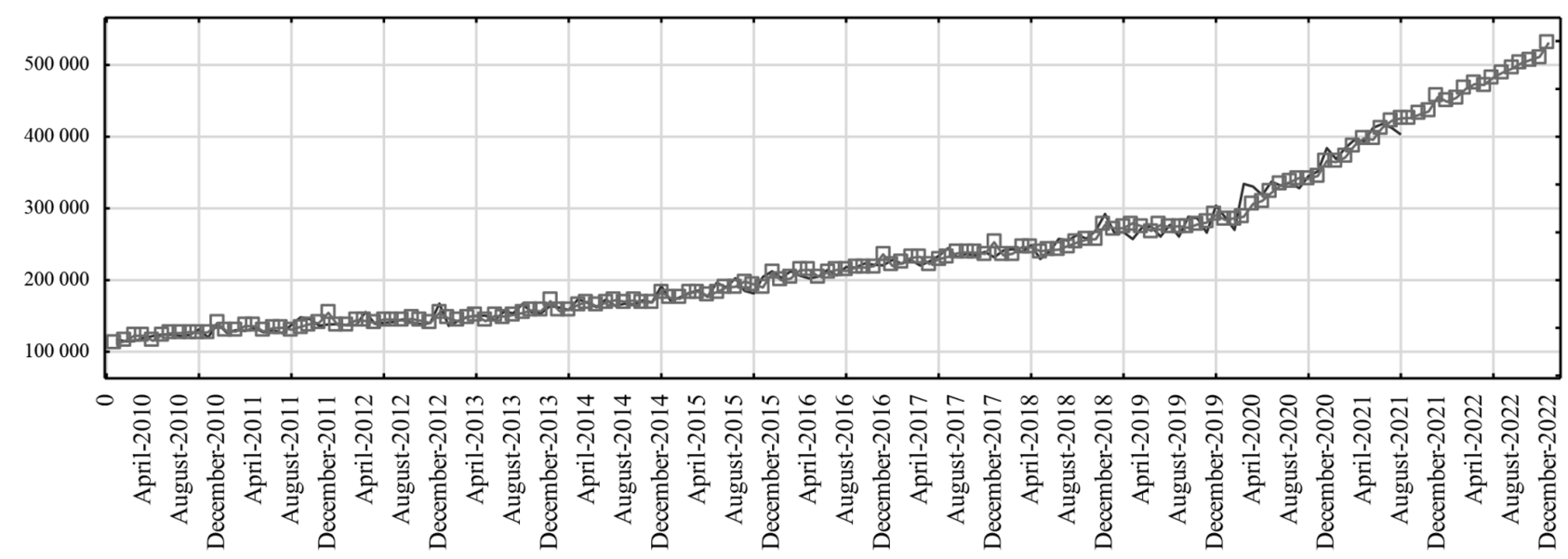

- Reserve money of the Central Bank

$\rightarrow-$ Holt's method forecast

Figure 12. Forecasting of the time series of the required cash reserves in the Central Bank in Poland for the years 2021-2022 in million PLN

Source: https://www.nbp.pl/home.aspx?f=/statystyka/pieniezna_i_bankowa/rezerwowy.html (Date of access: September 29, $202 \overline{1}$.

The evaluation of the forecasts obtained is the confirmation that a strong upward trend is maintained. The following table presents detailed forecasting results of the time series of statutory reserve of the central bank in mil PLN on a monthly basis during the years 2010-2021. The above-mentioned time series consisted of 140 out of 16 future periods and its analysis was conducted with the use of the Holt's method.

Table 3. Results of the forecast made by the Holt method and based on data concerning time series of reserve money of the central bank in mil PLN on a monthly basis during the years 2010-2021, consisting of 140 periods.

\begin{tabular}{|c|c|c|}
\hline Month-Year & Observation number & Holt's method forecast \\
\hline September-2021 & 141 & 426087,834 \\
\hline October-2021 & 142 & 430805,1 \\
\hline November-2021 & 143 & 435210,749 \\
\hline December-2021 & 144 & 455208,727 \\
\hline January-2022 & 145 & 448740,021 \\
\hline February-2022 & 146 & 454221,581 \\
\hline March-2022 & 147 & 466341,631 \\
\hline April-2022 & 148 & 473283,139 \\
\hline May-2022 & 149 & 472100,912 \\
\hline June-2022 & 150 & 482544,615 \\
\hline
\end{tabular}




\begin{tabular}{|c|c|c|}
\hline July-2022 & 151 & 489284,952 \\
\hline August-2022 & 152 & 494812,709 \\
\hline September-2022 & 153 & 502234,102 \\
\hline October-2022 & 154 & 506951,367 \\
\hline November-2022 & 155 & 511357,016 \\
\hline December-2022 & 156 & 531354,995 \\
\hline
\end{tabular}

Source: https://www.nbp.pl/home.aspx?f=/statystyka/pieniezna_i_bankowa/rezerwowy.html (Date of access: September 29, 2021.

The estimated amount of the required reserves at the Central Bank in Poland for 2021 is PLN 4923814 million while in 2022 it will increase to the level of approximately PLN 5833227 million. The monthly arithmetic average of the required reserves held at the Central Bank in Poland in 2021 will amount to PLN 410 317,8 million and in 2022 it will increase to PLN 486 102,3 million. The MAPE of the obtained forecast was at the level of $3,24 \%$. Thus, it should be assumed that the obtained forecast is very good.

\section{Conclusions}

The analysis and assessment of the time series of statutory reserves of the Polish central bank in mil of PLN indicates the existence of upward trend. This is a result of economic growth of Poland (which is measured using growth rate of real production or real national income) and protection against financial crises emerging around the world. As a result of conducted studies, the answer to the research question supports the need for analysing and assessment of series of statutory reserves of the central bank in Poland in millions of PLN during the years 2010-2021, in order to choose appropriate forecasting method and conduct a forecast. Applying the Holt method with the maintained upward trend of reserve money of the Polish central bank in mil PLN may improve forecasting for institutions dealing with analysis, assessment and forecasting of retrospective data concerning national economy. The forecast of required reserves at the Central Bank in Poland for 2021 is PLN 4923814 million while in 2022 it will increase to the level of approximately PLN 5833227 million. The MAPE of the obtained forecast was at the level of 3,24\%. Thus, it should be assumed that the obtained forecast is very good.

\section{References:}

Begg D., Vernasca G., Fischer S., Dornbusch R., 2014, Makroekonomia, Polskie Wydawnictwo Ekonomiczne, Warsaw.

Dittmann P. i in., 2011, 2016, Prognozowanie w zarzadzaniu sprzedaża i finansami przedsiębiorstwa (Forecasting in sales management and company finances), Wydawnictwo Nieoczywiste, imprint GAB Media.

Elliott G., Timmermann A., 2016, Economic forecasting, Princeton University Press, Princeton, Oxford.

Forlicz S. (red. naukowa), 2012, Zastosowanie metod ilościowych w ekonomii i zarządzaniu (Application of quantitative methods in economics and management), CeDeWu.pl, Warszawa.

Franses H.P., Dick van Dijk, Opschoor A., 2014 Time series models for business and economic forecasting, Cambridge University Press, Cambridge.

https://global.beyondbullsandbears.com/pl/2020/07/27/kryzys-wywolany-przez-pandemie-covid-19-przyspiesza-transformacjecyfrowa/ 19.11.2020.

Kot S. M., Jakubowski J., Sokołowski A., 2011, Statystyka, Difin, Warszawa.

Kozicki B., 2020, A New Method for Planning Needs in Terms of Security, International Business Information Management, Sewilla, Hiszpania.

Kozicki B., Waściński T., Brzeziński M., Lisowska A., 2018, Cost forecast in a shipping company, Transport means 2018, 2018ISSN 1822-296 X (print), ISSN 2351-7034 (on-line), 1235-1241.

Kuźniak M., red. Podgrodzka M., 2018, Wykorzystanie metod statystycznych w opisie zjawisk ekonomiczno-finansowych (Wykorzystanie metod statystycznych w opisie zjawisk ekonomiczno-finansowych, Oficyna Wydawnicza Szkoły Głównej Handlowej w Warszawie, Warszawa. 
Luisetto M., Fiazza C., Latiyshev O.Y. May 2020. COVID-19 Pandemia and the Management Strategy for Business and Economy \#COVID-19 \#Coronavirus \#Management \#Economy \#Emergency \#Infectious Disease \#Virologist, Management and Business Administration IMA Academy Lab, https://doi.org/10.13140/RG.2.2.27655.42401

Luszniewicz. A., 2003, Statystyka w zarządzaniu, Wydawnictwo Wyższej Szkoły Finansów i Zarządzania w Białymstoku (Statistics in management, Publishing House of the University of Finance and Management in Białystok), Białystok.

Narodowy Bank Polski; 2021, https://www.nbp.pl/home.aspx?f=/o_nbp/informacje/funkcje_banku_centralnego.html ; stan na dzień 12.10.2021.

Pike T.W., Saini V. 2020, An international comparison of the second derivative of COVID-19 deaths after implementation of social distancing measures. 03-04-2020, Available from: https://doi.org/10.1101/2020.03.25.20041475

Puławska-Turyna B., 2011, Statystyka dla ekonomistów (Statistics for economists); Diffin, Warszawa.

Raymond Chan H., Lee Spike Tsz Ho, 2014, Technical analysis and financial asset forecasting, World Scientific, New Jersey.

Satomi E., and other, April 2020. Alocação justa de recuros de saúde escassos diante da pandemia de COVID-19, Considerações éticas, Einstein (São Paulo 18(2):1-5, DOI: 10.31744/einstein_journal/2020AE5775).

Skudlik M., 2015, Planowanie i ocean rentowności przedsiębiorstwa (Planning and an assessment of the company's profitability), Wydawnictwo HELION, Gliwice.

Szubrycht T. 2006, Współczesne aspekty bezpieczeństwa, „Zeszyty Naukowe Marynarki Wojennej” (Contemporary aspects of security, „Scientific Papers of the Navy”), XLVII, Nr 4 (167), 87-98.

Tia H., and other. 2020. An investigation of transmission control measures during the first 50 days of the COVID-19 epidemic in China, Science, 1200 New York Avenue NW, Washington, DC 20005. The title Science is a registered trademark of AAAS, Science (print ISSN 0036-8075; online ISSN 1095-9203) is published by the American, Science 368, 638-642.

Yan Y., et al. 2020. The First 75 Days of Novel Coronavirus (SARS-CoV-2) Outbreak: Recent Advances, Prevention, and Treatment. Int J Environ Res Public Health, 17(7).

Zhu N., Zhang D., Wang W., Li X., Yang B., Song J., et al. 24 January 2020, A Novel Coronavirus from Patients with Pneumonia in China, 2019, New England Journal of Medicine.

Zimon G., Jurgilewicz M., Kmiotek K., Financial Security Management in Central Units of Purchasing Groups, WSEAS Transactions on Business and Economics, Volume 17, 2020, E-ISSN: 1109-9526, s. 910-920.

Marcin JURGILEWICZ is the Professor at Rzeszów University of Technology, PL. Research interests: internal security, law, mediation. ORCID ID: 0000-0003-2243-2165.

Norbert MALEC is the Professor at University of Natural Sciences and Humanities in Siedlce, PL. Research interests: international security.

ORCID ID: 0000-0003-0119-2705.

Juliusz PIWOWARSKI is the Professor at the University of Public Safety and Individual APEIRON in Krakow, PL. Research interests: international security.

ORCID ID: 0000-0002-9196-1194.

Bartosz KOZICKI is an assistant professor at the Military University of Technology, PL. Research interests: national security, internal security.

ORCID ID: 0000-0001-6089-952x. 
JOURNAL OF SECURITY AND SUSTAINABILITY ISSUES

ISSN 2029-7017 print/ISSN 2029-7025 online 